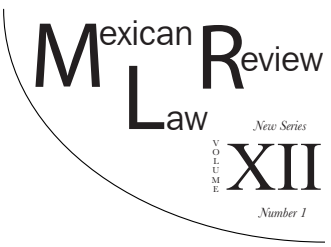

\title{
DIFFICULTIES IN IDENTIFYING UNACGOMPANIED REFUGEE CHILDREN IN MIXED MIGRATION FLOWS: THE CASE OF MEXICO AND CENTRAL AMERICA
}

\author{
Sergio Alejandro Rea Granados*
}

\begin{abstract}
This article aims to study and analyses the different problems, realities and challenges faced by children and adolescents that require international protection in the case of Mexico and Central America. This is due to the fact that the phenomenon of human mobility from a human rights perspective has not been a priority in the Americas region. On the contrary, this phenomenon is seen from a national security perspective, which causes that children and adolescents who require international protection are unnoticed as a result their human rights are easily attacked making them vulnerable. Due to international lawes on refugees, this article proposes to find possible solutions to protect their human rights and rights recognized by refugee law. Firstly, the identification of unaccompanied refugee children and adolescents within the mixed migratory flows in the case of Mexico and Central America. Secondly, it also aims to find possible solutions to give them access to the asylum procedure as a result to protect their rights such as non-refoulement and the best interests of the child. Rights not only recognized by international refugee laws, but also by international human rights law, which are mandatory and part of the international obligations on those countries of study.
\end{abstract}

KEYwORDs: Refugee children, invisibility of childhood, vulnerability, refugee law, and rights of children.

RESUMEN: Este artículo tiene la finalidad de estudiar y analizar los diferentes problemas, realidades y desafios que enfrentan los niños, niñas y adolescentes que requieren protección internacional en México y en Centroamérica. Lo anterior, debido a que el fenómeno de la movilidad humana desde una perspectiva de derechos humanos no ha sido una prioridad en la región de Las Américas. Al

* PhD in Law., Universidad de Chile, Santiago; LL.M in International Law., University of Melbourne, Australia; LL.B., Universidad Iberoamericana, Mexico City. Research Article, Funded by CONICYT-PCHA/Doctorado Nacional/2016-21160698 Orcid: available at http:// orcid.org/0000-0003-2672-8676. 
Esta revista forma parte del acervo de la Biblioteca Jurídica Virtual del Instituto de Investigaciones Jurídicas de la UNAM

contrario, este fenómeno es visto desde una perspectiva de seguridad nacional, la cual provoca que las personas menores de edad que requieren protección internacional pasen desapercibidas y sean agredidos sus derechos humanos haciéndolos vulnerables. Debido a la normas internacionales en materia de refugiados, este artículo propone encontrar posibles soluciones para proteger los derechos humanos de este grupo poblacional. Por una parte, la identificación de niños, niñas y adolescentes refugiados no acompañados dentro de los flujos migratorios mixtos en el caso de México y América Central. Asimismo, se tiene la finalidad de encontrar posibles soluciones para brindarles acceso al procedimiento de asilo y así proteger sus derechos como el de la no devolución y el interés superior del niño. Derechos no sólo reconocidos por el derecho internacional de los refugiados, sino también por el derecho internacional de los derechos humanos, los cuales son obligatorios en los países de estudio.

Palabras Glave: niños, niñas y adolescentes refugiados, invisibilidad de la niñez, situación de vulnerabilidad, derecho de los refugiados y derechos de los niños.

\section{TABle of Contents}

I. INTRODUCTION

II. Mixed Migration Flows

1. Differences between Refugees and Migrants....

2. Difficulties Facing Child Refugees and Asylum

Seekers Among Mixed Migration Flows.

III. Refugee GhildRen

IV. Unactompanied Refugee Ghildren............................................. 45

V. International Ghild Protection ................................................. 46

1. The Convention on the Rights of the Child .............................. 47

2. The 1951 Convention and Refugee Status................................ 49

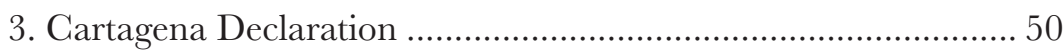

VI. LEGAL IMPLICATIONS..................................................................... 51

1. Non-Refoulement................................................................ 52

2. Access to the Asylum Procedure ................................................ 53

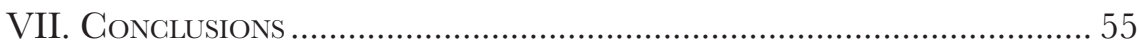

\section{INTRODUCTION}

In recent years mixed migration flows have occurred in numerous countries. Those who decide to migrate do so for different reasons: because of extreme poverty, to improve their working conditions or their quality of life, for family 
reunification purposes, as a result of persecution or because of a combination of these and other reasons. The diversity of migrant populations and the enormous challenges represented by their need to migrate means that mixed migration flows have become a highly complex phenomenon.

Amongst such populations, refugees represent an important group because of their unique status under international law. The right to seek asylum is enshrined in the UN Convention relating to the Status of Refugee and the 1967 Protocol, and in other universal and regional instruments. Despite this one of the most vulnerable population groups travels among refugees: unaccompanied children, who also utilize mixed migration flows to escape and find international protection. There are many reasons for children and adolescents to flee from their country of origin without the support of an adult. Those can include persecution, international conflicts and civil war, trafficking in various contexts and forms (including sale by parents), and the search for better economic opportunities.

This population has become more visible in the international arena since 2014, as there has been a notable increase in the number of unaccompanied children and adolescents arriving to the United States. ${ }^{1}$ In addition, the United Nations High Commissioner for Refugees (UNHCR) has stated that children in need of international protection remain in a particularly vulnerable situation and without access to protection. ${ }^{2}$ In the case of Mexico and Central America the matter has become more visible due to the difficulties and violations of their basic rights during their journey to their final destination, the United States and, to a lesser extent, to Canada.

This article aims, firstly, to delve into the complexity of mixed migration flows in Mexico and Central America. Secondly, it will identify why unaccompanied refugee children are one of the most vulnerable groups among mixed migration movements. And, finally, it will examine the role of international law in addressing these factors and in extending international protection to children among mixed migration movements.

\section{Mixed Migration Flows}

The phenomenon of migration has occurred throughout human history. It is often conceptualized as the movement of people from a certain point of origin to another across borders, or from their place of birth to a destination

1 Katie Zezima and Ed O'Keefe, Obama calls wave of children across U.S.-Mexican border urgent humanitarian situation, The Washington Post, June 2, 2014, available at http://wrere. washingtonpost.com/politics/obama-calls-wave-of-children-across-us-mexican-border-urgent-humanitariansituation/2014/06/02/4d29df5e-ea8f-11e3-93d2-edd4be1f5d9e_story.html.

2 U.N. UnhCR, Regional Office for Mexico, Guba and Gentral America, The International Protection of Unaccompanied or Separeted Ghildren Along the Southern Border of Mexico (2008). 
across international borders. In sum, migration is a complex phenomenon that involves two or more States as countries of origin, transit, and destination.

According to International Organization for Migration, mixed flows are defined as complex population movements. The complexity is due to the fact that these movements normally encompass a combination of refugees, asylum seekers, economic migrants, environmental migrants, victims of human trafficking, and others. ${ }^{3}$ These complex movements are often realized through unconventional or irregular means that make the phenomenon much more difficult to identify, and makes the different motivations of migrants difficult to determine. For instance, in 2013, there were 232 million international migrants worldwide; in the Americas alone there were approximately $61,617,229$ migrants. ${ }^{4}$ According to UNHCR, as of late 2014 around 806,000 persons on the Americas were refugees or persons needing international protection. The main reason for the sharp increase in the number of asylum seekers is a combination of armed conflicts, deterioration of security or humanitarian situations, and human rights concerns in a number of countries. ${ }^{5}$ In addition, the Americas continue to witness large-scale mixed movements originating from within and outside the region by land and sea, in addition to the trafficking of human beings. According to U.S. Customs and Border Protection, between October 2013 and September 2014, a total of 67,339 unaccompanied children and a further 68,445 family units were apprehended along the United States southern border. ${ }^{6}$

The greatest challenge in the region with regards to migration is the implementation of effective identification and referral mechanisms for vulnerable migrants and refugees both at borders and within national territories. ${ }^{7}$ Thus, it is necessary to identify and/or develop appropriate tools for identifying people in need of international protection amongst mixed migration flows.

\section{Differences between Refugees and Migrants}

In any analysis of migration, a basic distinction between refugees and other migrants is essential. The criteria for distinction is based on the moti-

3 International Organization for Migration (IOM), International Migration Law: Glossary on Migration 42 (2004).

4 U.N. Dep't of Int'L ECON. \& SOG. Affairs, International Migration Report: Levels And Trends In International Migrantstock, U.N. Doc. ST/ESA/SER.A/346, New York (2013).

5 UnHCR, UNHGR Asylum Trends, 2014: Levels and Trends in Industrialized COUNTRIES 7 (2015).

${ }^{6}$ U.S. Dep't of Homeland Security, Customs and Border Protection, Southwest Border Unaccompanied Alien Children (2015), available at http://wrerrecbp.gov/newroom/stats/ southwest-border-unaccompanied-children.

7 U.N. UnhCr, Refugee Protection and International Migration: Trends August 2013-JULY 2014, at 16 (2014). 
vations for migrating from the country of origin to another country. Whilst those in the former category are forced to migrate, those in the latter choose to move voluntarily. In addition, if refugees return to their country of origin, they would be seriously threatened in their essential rights to life, security and freedom. The latter voluntarily leave their country in order to take up residence elsewhere, and migrants returning to their country of origin would not suffer persecution. They may be moved by the desire for change or adventure, or by family or other reasons of a personal nature. If they are moved exclusively by economic considerations, they are economic migrants and not refugees. ${ }^{8}$ Although the differences between migrants and refugees may seem simplistic, the truth is that it has become increasingly difficult to accurately divide migrants into separate categories, given that the causes of displacement may be several, which are often interrelated or unclear. ${ }^{9}$ Real factors can remain hidden as part of the complexity of migration movements, which is constantly influenced by changing migration trends, social and economic dynamics, transportation methods, transit routes and entry points.

To illustrate the importance of identifying potential refugees in the context of mixed migration movements and the risks of making simplistic distinctions, let's take poverty and inequality as key factors. At first appraisal, both could be easily deemed causes of economic-related migration. However, behind a country's economic standards, which affect a person's livelihood, there may also be discriminatory measures against persons because of nationality, race, religion, political opinion or because of membership in a particular group. The UNHCR has stated that persecution arises if discriminatory measures lead to consequences of a substantially prejudicial nature for the person concerned. In other words, if such measures endanger or destroy the economic, social or cultural existence of a particular group, e.g. by imposing serious restrictions on their right to earn a livelihood, their right to practice a religion, or their right to access public educational facilities. ${ }^{10}$ In this light, poverty and inequality become relevant factors for granting refugee status because there are political elements involved in meeting the refugee definition. Making a correct appraisal of the migrant or refugee status requires a thorough examination of all circumstances, and characterization on a case-by-case basis.

Persecution, therefore, may also be determined by means of aggregating a number of lesser violations, ${ }^{11}$ such as those of social, economic and cultural character within the scope of the rights defined by the 1966 Covenant on Economic, Social and Cultural Rights. The Covenant contemplates the pro-

8 U.N. UnHCR, Handbook and Guidelines On Procedures and Criteria for Determining Refugee Status Under the 1951 Convention and the 1967 Protocol Relating to THe Status of Refugees 16 (2011).

9 U.N. UNHCR, Sovereignty and Irregular Migration: The Dynamics of Irregular Movement Through Colombia and Ecuador 4 (2013).

10 UNHCR, at 7, 14 [54].

11 Oh v. Minister of Citizenship and Immigration (2009). 
gressive implementation of said rights through various obligations levied on State Parties including an avoidance of the adoption of regressive measures, safeguarding the core elements of each right, and ensuring non-discrimination in the enjoyment of such rights. ${ }^{12}$

Restrictive or discriminatory measures must be assessed in the light of all circumstances of a particular case. With regards to children, these are important elements because they are essential rights that must not be limited. For example, birth registration is of utmost relevance to reduce statelessness, as well as to prevent exclusion from educational and health services, ${ }^{13}$ each of these three essential rights on its own fulfills the definition of a refugee. In Central America and Mexico it has been reported that one of the main reasons for unaccompanied child migration is that children have experienced some sort of social exclusion including but not limited to deprivation of education, employment opportunities, medical services, and even food. ${ }^{14}$

Another example that explains the difficulties in the identification of refugees from other migrants is when a person is affected by a radical change of circumstances after leaving his or her country of origin. One example of this is when he or she has left for purely economic reasons, but then other circumstances occurring in his/her country of origin while traveling or during his/ her absence makes him/her the target of persecution and, as a result, he/she qualifies for refugee status. This is what is called a refugee sur place, namely, a refugee who was not a refugee when he or she left his or her country, but became a refugee at a later date. ${ }^{15}$

As mentioned, distinguishing between a refugee and a migrant is becoming more difficult and complex. Although the traditional distinction criteria by which those who choose to move voluntarily are migrants and those who are compelled to do so are refugees, seems to be a fairly clear-cut one, there are a myriad of factual circumstances that can blur the line of distinction. Nonetheless, according to the Inter-American Court of Human Rights, States are compelled within their territorial jurisdictions to identify foreign people requiring international protection, either as refugees or otherwise, through an initial evaluation with guarantees of safety and confidentiality in order to provide them with adequate and individualized protection measures. ${ }^{16}$ The establishment of procedures to clearly identify these people and

12 U.N. Commission on Human Rights, Note Verbal Dated 86/12/05 From the Permanent Mission of the Netherlands to the United Nations Office at Geneva Addressed to the Centre for Human Rights ("Limburg Principles"), 43rd sess, UN Doc E/ CN.4/1987/17 at B.16 21-22 (1987).

13 Committee on the Rights of the Child (CRG), General Comment No. 9: The Rights of Children with Disabilities, $43^{\text {RD }}$ sess, UN Doc CRG/C/GG/9, 35-36 (2007).

14 Centre for Gender \& Refugee Studies, Childhood and Migration in Central and North America: Causes, Policies, Practices and Challenges 8 (2015).

15 UNHCR, at 7, 19 [94].

16 Rights and Guarantees of Children in the Context of Migration and/or in Need of International Protection (Advisory Opinion OC-21/14), Inter-Am Court HR, 34 [82] (2014). 
process requests in a timely and effective manner for international protection constitutes a positive obligation of State agencies as well as Courts; failing to implement them effectively may constitute a lack of due diligence and eventually result in State liability. ${ }^{17}$ In the Americas there is an international obligation for both transit and destination States to identify individuals in need of international protection from other migrants not in need of such protection, including with regards to unaccompanied children among mixed migration movements.

\section{Difficulties Facing Child Refugees and Asylum Seekers Among Mixed Migration Flows}

Within mixed migration movements, most of the refugees and asylum seekers, including children, move from one country to another in an irregular manner and in precarious conditions. These movements generally take place without legal documentation and frequently involve human smugglers and traffickers, migrants place their lives at risk as they are obligated to travel in inhumane conditions and as a result they may be exposed to abuse and exploitation. Generally, refugees and asylum seekers try to avoid screening processes by official authorities because they fear being detained and returned to their country of origin, from where they tend to be fleeing. Many of them may be escaping from persecution by state actors, resulting in heightened levels of trauma and fear. This results in severe distress and fear of being persecuted by the authorities of either the transit or the destination state. For these reasons, refugees and asylum seekers prefer travelling unnoticed, making their identification and classification difficult. The Inter-American Commission on Human Rights has argued that migrants in irregular situations, including refugees and asylum seekers, are the most vulnerable because they are in the greatest danger of being victims of rights abuses and violations. ${ }^{18}$

Despite the aforementioned difficulties, States must take all necessary measures to identify unaccompanied children requiring international protection at the earliest possible stage, including at the border. ${ }^{19}$ To do this, it is neces-

17 Velásquez Rodríguez Case v. Honduras, 4 Inter-Am HR (Ser. G), 31 -33 [164-177] (1988).

18 In the Commission's view, migrants in an irregular situation face a structural vulnerability in which they are subject to arbitrary arrest and a lack of due process; collective deportation; discrimination in access to the public and social services to which foreign-born nationals of other states are entitled by law; inhumane detention conditions; unlawful harassment by police and immigration authorities; obstacles in accessing and getting justice for crimes committed against them and an inability to defend themselves when exploited by unscrupulous employers.

Inter-American Commission on Human Rights, Human Rights of Migrants and other Persons in the context of Human Mobility in Mexico, OAS Doc Ser L/V/VII 41 [82-83] (2013).

19 CRC, General Comment No. 6: Treatment of Unaccompanied and Separated Children Outside their Country of Origin, $39^{\text {th }}$ sess, UN Doc CRG/GC/2005/6, 7 (2005). 
sary to interview all unaccompanied children in order to properly identify a child at risk and later to decide how to handle cases involving children based on information obtained in interviews. States must also consider factors such as child's maturity, age, and vulnerability. This is imperative because children may not be in a position to provide relevant information about their experiences to unknown persons, particularly regarding the traumatic situations that they may have suffered. As a result, they may not be able to provide accurate information with proper context, information on timing, and details of events the way adults can. Similarly, children may only have very limited knowledge of the conditions in their country of origin. ${ }^{20}$ Often, adult individuals themselves may not be aware of the full reasons of the persecution they fear. It is not, however, up to immigration officers to delve into their cases to such an extent as to ascertain such reasons in detail. ${ }^{21}$ Whether obtained from adults or children, all information gathered should be considered relevant to identify potential unaccompanied refugee children.

Another challenge is that in Mexico and the United States, unaccompanied children are routinely denied entry or are detained at the border by immigration officers. This means not only that they are denied access to asylum procedures; but also, points to a failure to provide counseling and information about their rights, ${ }^{22}$ including the right to seek and receive asylum. This amounts to a limitation of their access to this right, especially considering most unaccompanied children likely lack such knowledge.

A further difficulty is that either at the starting point or while on route, criminal smuggling and trafficking is often the sole option to reach the destination, and thus, protection. Illegal activities can also represent obstacles to the proper and timely identification of refugees who are minors. Moreover, depending on the level of sophistication, control or disregard employed by perpetrators, victims may continue to experience fear or harm while travelling and even after reaching their destination. It is also possible that they could be blackmailed regarding their own situation in the destination country or by way of their relatives and families remaining in the country of origin. According to the Unaccompanied Children's Services Division of the US Department of Health and Human Services, human smuggling through criminal organizations has become especially troublesome due to the physical and psychological effects on children. Increasingly, children have become targets for physical and sexual abuse by traffickers during their journey to the United States. It is not uncommon for the Unaccompanied Children's Services Division to assist children that have arrived in the United States claim-

20 U.N. UNHCR Guidelines on Determining the Best Interests of the Child 60 (2008).

21 Handbook and Guidelines on Procedures and Criteria for Determining Refugee Status under the 1951 Convention and the 1967 Protocol Relating to the Status of Refugees, above n 8,16 [66].

22 Centre for Gender \& Refugee Studies, above n 14, 17-21. 
ing special needs or requiring specialized professional services due to teenage pregnancy, acute mental illnesses or psychological trauma, severe depression, and otherwise. ${ }^{23}$

There are many other reasons unaccompanied children are particularly vulnerable to human trafficking. One is because they are unable to keep contact with either their families left behind or with the authorities of the country of asylum or transit. Further, specific profiles of children and adolescents contribute to the vulnerability of being trafficked e.g. victims may be targeted on the basis of their ethnicity, gender, age, social subsets, economic situation, and lack of education and opportunities, to name a few.

Finally, it is worth mentioning that not all children are victims or potential victims of trafficking, within the scope of the refugee definition. ${ }^{24}$ However, belonging to such a group may be a factor contributing to double victimization. Despite the fact they cannot benefit from the 1951 Convention and the Cartagena Declaration; minors may be eligible for complimentary protections that guarantee the rights of children. ${ }^{25}$

\section{Refugee ChiLdRen}

According to the Committee on the Rights of the Child, enjoyment of the rights stipulated in the Convention on the Rights of the Child (CRG) is not limited to children who are citizens of a State Party. Such rights - if not explicitly stated otherwise in the Convention - must be available to all chil-

23 Chad C. Haddal, Unaccompanied Alien Children: Policies and Issues 19 (2007).

24 UnhCR, Guidelines on International Protection No. 7: The Application of Article 1A(2) Of The 1951 Convention and/or 1967 Protocol Relating to the Status of Refugees to Victims of Trafficking and Persons at Risk of Being Trafficked, UN Doc HCR/GIP/06/07, 3 (2006).

25 Since the phrase 'complementary protection' is not a term defined in any international instrument, it seems prudent from the outset to understand the nature of the protection regimes that this study aims to examine. The term 'complementary protection' has emerged over the last decade as a description of the increasingly apparent phenomenon in industrialized countries of relief from removal being granted to asylum seekers who have failed in their claim for 1951 Convention refugee status. Complementary protection is a generic phrase, with the actual terminology used by states to describe such forms of protection in their territory, including any attached immigration status, varying enormously: 'subsidiary protection,' 'humanitarian protection' and 'temporary asylum' are just a few examples.

What all these initiatives have in common is their complementary relationship with the protection regime established for refugees under the 1951 Convention/1967 Protocol. They are intended to provide protection for persons who cannot benefit from the latter instruments even though they, like Convention refugees, may have sound reasons for not wishing to return to their home country.

UNHCR, Protection Mechanisms Outside of the 1951 Convention "Complementary Protection", UN Doc PPLA/2005/02, 2 (2005). 
dren, including asylum seekers, refugee and migrant children, irrespective of their nationality, immigration status or statelessness. ${ }^{26}$ There is an obligation for States, in all circumstances and without distinction of any kind, to respect all human rights of persons under their territorial jurisdiction. Therefore, when a child migrant is identified, that child must receive information about their rights including the right to seek and receive asylum and all necessary guidance as to the procedure to be followed ${ }^{27}$ before a clearly identified authority. ${ }^{28}$ This could be the first step in identifying children in need of international protection among mixed migration flows.

As already identified, children are one of the most vulnerable population groups at risk of persecution due to their condition and their physical and emotional development. Further, children are exposed to specific forms of persecution. ${ }^{29}$ Indeed, children can become victims of recruitment into armed forces or armed groups such as gangs and organized crime organizations, or be forced into sexual exploitation, gender-based violence, child trafficking, abuse and several other forms of violence. Refugee children face the same forms of persecution as adults, but may experience them differently - most of the time, in an aggravated manner - when factors such as immaturity, vulnerability, undeveloped coping mechanisms, and social, economic, and emotional dependency are taken into account.

Although refugee children are entitled to access the same protection as adult refugees, in relation to substantive aspects of refugee law and related-procedures their special vulnerabilities require adopting an age-sensitive approach, ${ }^{30}$ especially when special forms of persecution against them are clearly identified. Similarly, the Committee for the Rights of the Child of the Office of the United Nations High Commissioner for Human Rights has argued that States must implement age and gender sensitive asylum procedures, and that the interpretation of refugee status must be age and gender sensitive. $^{31}$

Child-sensitive screening and referral procedures mean that asylum claims made by unaccompanied children should be processed on a priority basis and they will be entitled to special protection and consideration for their as-

26 General Comment No. 6: Treatment of Unaccompanied and Separated Children Outside their Country of Origin, above n 19, 7.

27 Executive of the United Nations High Commissioner for Refugees (ExCom), Determination of Refugee Status, 28 sess, 8, (1977), e (ii).

28 Ibid. at (iii).

29 Ibid. at b and $\mathrm{x}$ (viii).

30 This argument is based on the importance of certain factors that should be taken into account regarding children such as their age, their level of maturity and development and their dependence on adults.

31 General Comment No. 6: Treatment of Unaccompanied and Separated Children Outside their Country of Origin, above n 19, 18. 
sistance needs, for instance, those arising from physical and psychological abuses that they may have suffered while travelling.

Another feature of child-sensitive asylum procedures is that in the case of unaccompanied or separated children, tailored interventions in child protection are required, as are independent, qualified guardians, ${ }^{32}$ who need to be appointed immediately. ${ }^{33}$ Children are entitled to legal representation by guardians who are properly trained and capable of supporting them throughout the procedure. ${ }^{34}$

Before any action is taken, it is essential to conduct a best-interest assessment ${ }^{35}$ for each individual child so as, to ensure sufficient focus on the child's well-being and the protection of their rights when choosing the most appropriate and durable solution; as well as determining the right timing for the adoption of said solution. The assessment must take into account a wide range of factors ${ }^{36}$ and determine which of the available options is best suited to the child's specific circumstances in order to guarantee protection of his/ her rights. This may require multiple reviews carried out by several qualified staff, agencies or relevant stakeholders.

Usually, the most appropriate and long lasting solution for unaccompanied children is tracking down their parents or relatives and promoting family reunification. However, in exceptional situations, children's rights experts might find a case where a regular solution is unavailable, unsuitable or even counterproductive, for instance, where returning the child to their parents or relatives might put the child at risk, as when an infant has been subjected to abuse or persecution by his/her parents or family members. ${ }^{37}$ In the context of Mexico and Central America, the UNHCR has stated that a significant

32 "Guardian" here refers to an independent person with specialized skills who looks after the child's best interests and general wellbeing. Procedures for the appointment of a guardian must not be less favourable than the existing national administrative or judicial procedures used for appointing guardians for children who are nationals in the country. "Legal representative" refers to a lawyer or other person qualified to provide legal assistance to, and inform, the child in the asylum proceedings and in relation to contacts with the authorities on legal matters.

33 ExCom, Children at risk, 58 sess, 107 (2007), g (viii).

34 Ibid.

35 A best interest determination describes the formal process designed to determine the child's best interests for particularly important decisions affecting the child that require stricter procedural safeguards. Such process should ensure adequate child participation without discrimination. It should also allow the views of the child to be given due weight in accordance with age and maturity. It involves decision-makers with relevant areas of expertise, and balances all relevant factors in order to assess the best option. Ibid. at 23.

36 Information relating to conditions in countries of origin, motivations for movements, transportation means, transit routes and entry points. An international or regional organization may be well placed to offer support to this function.

UNHCR, Refugee Protection and Mixed Migration: a 10.point Plan of Action, at 2 (2011).

37 UNHCR, Guidelines on Determining the Best Interests of the Child, above n 20, 36. 
percentage of children have fled from their countries of origin because they have suffered from domestic violence by their caretakers. ${ }^{38}$

Considering these facts, in the case of harm inflicted or serious concerns related to potential domestic violence, temporary care should be provided until an appropriate and durable solution is found. This care must be provided by an appropriate care institution, capable of delivering the main necessities to children, without exposing them to risk. ${ }^{39}$ In the case of Mexico, the Federal Protection Agency for Children and Adolescents, the institution in charge of child protection, must take into account important measures for the best interests of children.

However, there is also a negative interpretation of temporary care. One example of this is the situation of unaccompanied children in Mexico, as Mexican administrative immigration authorities restrict their freedom in the name of protecting their rights to safety and physical integrity. ${ }^{40}$

It is also important to note that adopting a child-sensitive approach on asylum policies and legislation does not necessarily mean that child asylum seekers are automatically entitled to refugee status. ${ }^{41}$ Each child's case must be interpreted in accordance with the definition of refugee established in the 1951 Refugee Convention or in the Cartagena Declaration. Despite this, children who do not meet the universal definition or the broader definition of

38 U.N. UNHCR, Children on the run: Unaccompanied Children Leaving Central America and Mexico and the need for International Protection 7 (2014).

39 Wider environmental risk factors include, but are not limited to: an insecure environment; lack of access to child-sensitive asylum procedures; situations of displacement, particularly protracted situations; statelessness; lack of sustainable solutions; poverty and families' lack of self-reliance opportunities; inadequate access to and use of services such as education and health care; disruption of family and community support structures; prevalence of traditional practices that are harmful to children; discrimination, intolerance, xenophobia, and gender inequality; lack of documentation of the parent-child relationship through birth registrations and issuance of birth certificates. There are also individual risk factors, including, but not limited to: unaccompanied and separated children, particularly those in child-headed households as well as those accompanied by abusive or exploitative adults; stateless children; adolescents, in particular underage mothers and their children; child victims of trafficking and sexual abuse, including pornography, pedophilia and prostitution; survivors of torture; survivors of violence, in particular sexual and gender-based violence and other forms of abuse and exploitation; children who are married under the age specified in national laws and/or children in forced marriages; children who are or have been associated with armed forces or groups; children in detention; children who suffer from discrimination; children with mental or physical disabilities; children living with or affected by HIV or AIDS; children suffering from other serious diseases; and children out of school. ExCom, above n 27, c.

40 Comisión Nacional de Derechos Humanos, Informe sobre la problemática de niñas, niños y adolescentes centroamericanos en contexto de migración internacional no acompañados en su tránsito por México, y con necesidades de protección internacional, at 50 (2016).

41 U.N. UnhCR, Guidelines on International Protection No. 8: Child Asylum Claims Under Articles 1(A) 2 And 1(F) of the 1951 Convention and/or 1967 Protocol Relating to the Status of Refugees, HCR/GIP/09/08, 3 (2009). 
refugee, should be given other legal status during over the period required to protect their rights, safety and security. This could take the form of complimentary or subsidiary protection.

In accordance with the $\mathrm{CRC}$, it is stipulated that children must be protected from any risk of irreparable harm. In the case of unaccompanied children the argument applies even more, for they are generally escaping violence perpetrated by armed criminal organizations, even if it is not the only reason. ${ }^{42}$ Underscoring this idea, Goodwin-Gill and McAdman argue that children fleeing from generalized violence may have a right to protection arising from the CRC's requirement that a child's best interest be a primary consideration in all actions concerning them. ${ }^{43}$

\section{Unaccompanied Refugee Children}

According to the United Nations, unaccompanied children are children who have been separated from parents as well as other relatives, and who are not being cared for by an adult who, by law or custom, is responsible for doing so. ${ }^{44}$ In turn, separated children are those who have been separated from both parents or from their previous legal or customary primary caregiver, but not necessarily from other relatives. The latter may, therefore, include children accompanied by other adult family members. ${ }^{45}$

The separation of children from their parents or caretakers may occur for a number of reasons. It could be because the child has witnessed or suffered violence, or experienced the disappearance or killing of their parents or another person on whom the child depends, or they may have a well-founded fear of persecution, even if they are not the direct target. ${ }^{46}$ Under certain circumstances, the forced separation of a child from his or her parents is due to discriminatory custody laws or the detention of the child's parents, this could amount to persecution. ${ }^{47}$ Therefore, it can be said that in some child asylum cases, the agent of persecution is frequently a non-state actor, can include her or his parents, caregivers or guardians. In Mexico and Central America some of the unaccompanied children have fled from their country of origin due to the consequences of domestic violence they have suffered in their homes. ${ }^{48}$

42 Children on the run: Unaccompanied Children Leaving Central America and Mexico and the need for International Protection, at 33, 46-51.

43 Guy S. Goodwin-Gill and Jane McAdam, The Refugee in International Law 324 (OUP, 3ed. 2007).

44 General Comment No. 6: Treatment of Unaccompanied and Separated Children Outside their Country of Origin, at 19, [7].

45 Ibid. at 8.

46 Çiçek v. Turkey 67124/01 Eur Court HR [173-174] (2005).

47 EM (Lebanon) v. Secretary of State for the Home Department, 5-6 UKHL 64 (2008).

48 UNHCR, at 35, 6. 
But also, it is not the only reason as mentioned above. Such harm has been recognized as potential basis for providing international protection, because of the child's vulnerability, dependency and, in many cases, the lack of ability to seek or be provided protection by the State. ${ }^{49}$

Another situation of vulnerability in which unaccompanied refugee children frequently find themselves in their journey is the absence of authorities from the State of origin or any other supporting adult. As a consequence, the vulnerability of the child increases, as they face obstacles against the full and effective protection of both their human rights and their rights as children.

On a different subject, although girls and boys face many of the same protection risks, they may also experience protection challenges related to their gender. ${ }^{50}$ Taking into consideration gender and age factors, girls may suffer further vulnerability. This means there needs to be a clear understanding of the differences between sex and gender. According to the UNHCR, gender refers to the relationship between women and men based on socially or culturally constructed and defined identities, status, roles, and responsibilities that are assigned to one sex or another; while sex is a biological determination. ${ }^{51}$ Thus, a gendered approach should be considered in the identification of potential refugees so as to ensure equitable access to asylum procedures. This approach can help to clarify the specific forms of persecution most often feared by girls and women, for example: sexual and domestic violence; punishment, including accusations of adultery and discrimination for transgression of social mores; sexual orientation; female genital mutilation; and trafficking. Gender is not the only relevant factor for identifying types of persecution, age considerations are equally important in the identification of potential girl refugees amongst mixed migration flows. In sum, it is essential that the construction of the definition of refugee be inclusive enough to take into account both age and gender perspectives. ${ }^{52}$

\section{International Ghild Protection}

There are a number of international instruments offering specific guidance regarding the rights and needs of children: the 1989 United Nations Convention on the Rights of the Child; the Optional Protocol to that Convention, on the sale of children, child prostitution and child pornography; the

49 Ibid. at 46.

50 ExCom, at 30, fourth paragraph.

51 UnhCR, Guidelines on International Protection: Gender-Related Persecution within the Context of Article 1A(2) OF the 1951 convention and/or its 1967 Protocol on the Status of Refugees, UN Doc HCR/GIP/02/01, 3 (2002).

52 Alice Edwards, Age and gender dimensions in international refugee law' Erika Feller, Volker Türk and Frances Nicholson (eds) Refugee Protection in International Law: UNHCR's Global Consultations on International Protection 48 (Cambridge University Press, 2003). 
1980 Hague Convention Number 28 on Civil Aspects of International Child Abduction; the Trafficking Protocol; and the International Labor Organization (ILO) Convention Number 182 on the Prohibition of the Worst Forms of Child Labor to name just a few. The 1951 Convention relating to Refugees makes no distinction between children and adults and thus applies to both. In turn, the Convention on the Rights of the Child establishes particular rights and principles applicable to all children, which supplements the meaning and scope of the 1951 Refugee Convention.

One example of this is the principle of child's best interests, ${ }^{53}$ which entails priority consideration in the design of public policies and in drafting laws and regulations concerning childhood as well as in their implementation in all spheres that relate to the life of a child, ${ }^{54}$ including when he or she demands international protection.

\section{The Convention on the Rights of the Child}

Since there are relevant principles and rights applicable to children, most of which are enshrined in the Convention on the Rights of the Child, a child sensitive understanding of refugee policies and actions is required. As to the former, there are four general principles, which must be of primary consideration in all actions affecting children, including unaccompanied refugee children. These principles are: the best interests of the child, no discrimination, the right to life ensuring to the extent possible the survival and development of the child, and the right to express their views freely. In their analysis of the best interests of the child, Jacqueline Bhabha and Wendy Young have said that this principle, as derived from Article 3 of the Convention on the Rights of the Child, operates as an interpretative aid to international refugee law, broadening and deepening the scope of protection, both in terms of substantive law and procedural mechanisms. ${ }^{55}$

The rights of the child include, but are not limited to: the right not to be separated from parents, ${ }^{56}$ protection from all forms of physical and mental

53 Also, this principle describes the formal process with strict procedural safeguards designed to determine the child's best interest in particularly important decisions affecting the child. It should facilitate adequate child participation without discrimination, involve decisionmakers with relevant areas of expertise, and balance all relevant factors in order to assess the best option. UNHCR Guidelines on Determining the Best Interests of the Child, above n 20, 8.

${ }^{54}$ Juridical Status and Human Rights of the Child, (Advisory Opinion OG-17/02), No 17, [28 August 2002], Inter-Am Court HR (Ser A), second operative paragraph.

55 U.N. UnHCR, Guidelines on International Protection: Gender-Related PerseCUtion within the Context of Article 1A (2) OF the 1951 convention and/or its 1967 PROtOcol on the Status of Refugees, UN Doc HCR/GIP/02/01, 3 (2002).

56 Article 9. (1) States Parties shall ensure that a child shall not be separated from his or her parents against their will, except when competent authorities subject to judicial review deter- 
violence, abuse, neglect, and exploitation, ${ }^{57}$ protection from traditional practices prejudicial to the health of the child, ${ }^{58}$ a standard of living adequate for child development ${ }^{59}$ the right not to be detained or imprisoned unless as a last resort measure, ${ }^{60}$ and protection from under-age recruitment. ${ }^{61}$ The Convention also recognizes the right of refugee children and children seeking refugee status to appropriate protection and humanitarian assistance in the enjoyment of applicable rights set forth in the Convention. ${ }^{62}$

mine, in accordance with applicable law and procedures, that such separation is necessary for the best interests of the child. Such determination may be necessary in a particular case such as one involving abuse or neglect of the child by the parents, or one where the parents are living separately and a decision must be made as to the child's place of residence.

57 Article 19. (1) States Parties shall take all appropriate legislative, administrative, social and educational measures to protect the child from all forms of physical or mental violence, injury or abuse, neglect or negligent treatment, maltreatment or exploitation, including sexual abuse, while in the care of parent(s), legal guardian(s) or any other person who has the care of the child.

58 Article 24. 1. States Parties recognize the right of the child to the enjoyment of the highest attainable standard of health and to facilities for the treatment of illness and rehabilitation of health. States Parties shall strive to ensure that no child is deprived of his or her right of access to such health care services. 2. States Parties shall pursue full implementation of this right and, in particular, shall take appropriate measures: (a) To diminish infant and child mortality; (b) To ensure the provision of necessary medical assistance and health care to all children with emphasis on the development of primary health care; (c) To combat disease and malnutrition, including within the framework of primary health care, through, inter alia, the application of readily available technology and through the provision of adequate nutritious foods and clean drinking-water, taking into consideration the dangers and risks of environmental pollution; (d) To ensure appropriate pre-natal and post-natal health care for mothers; (e) To ensure that all segments of society, in particular parents and children, are informed, have access to education and are supported in the use of basic knowledge of child health and nutrition, the advantages of breastfeeding, hygiene and environmental sanitation and the prevention of accidents; ( $f$ ) To develop preventive health care, guidance for parents and family planning education and services. 3. States Parties shall take all effective and appropriate measures with a view to abolishing traditional practices prejudicial to the health of children. 4. States Parties undertake to promote and encourage international co-operation with a view to achieving progressively the full realization of the right recognized in the present article. In this regard, particular account shall be taken of the needs of developing countries.

59 Article 27 (1) States Parties recognize the right of every child to a standard of living adequate for the child's physical, mental, spiritual, moral and social development.

60 Article 37. States Parties shall ensure that: (a) No child shall be subjected to torture or other cruel, inhuman or degrading treatment or punishment. Neither capital punishment nor life imprisonment without possibility of release shall be imposed for offences committed by persons below eighteen years of age;

61 Article 38 (1) States Parties undertake to respect and to ensure respect for rules of international humanitarian law applicable to them in armed conflicts, which are relevant to the child.

62 Article 22. (1) States Parties shall take appropriate measures to ensure that a child who is seeking refugee status or who is considered a refugee in accordance with applicable interna- 


\section{The 1951 Convention and Refugee Status}

For international protection to be granted, an individual must satisfy the definition of refugee according to this international instrument. It is accorded to individuals when governments are unwilling or unable to protect their citizens, who suffer serious violations of their rights and thus are forced to leave their homes and families behind to seek safety in another country. It also requires that such a person has a well-founded fear of being persecuted for reasons of race, religion, nationality, membership of a particular social group or political opinion.

In Central America and Mexico, organized crime and domestic violence ${ }^{63}$ represent two overarching patterns of harm related to potential requests for international protection. Although these are the most common justifications employed by potential candidates, they are far from being unique, and other possible factors could amount to persecution, which could also be derived from a combination of two or more of these factors. ${ }^{64}$

There might be children who do not meet the refugee definition of the 1951 Convention or the 1967 Protocol but, who nevertheless are in need of international protection due to the fact that they are unsafe and unable to receive state protection in their country of origin. ${ }^{65}$ As a result, some of these children may fall within the broader definition enshrined in the Cartagena Declaration.

tional or domestic law and procedures shall, whether unaccompanied or accompanied by his or her parents or by any other person, receive appropriate protection and humanitarian assistance in the enjoyment of applicable rights set forth in the present Convention and in other international human rights or humanitarian instruments to which the said States are Parties.(2) For this purpose, States Parties shall provide, as they consider appropriate, co-operation in any efforts by the United Nations and other competent intergovernmental organizations or nongovernmental organizations co-operating with the United Nations to protect and assist such a child and to trace the parents or other members of the family of any refugee child in order to obtain information necessary for reunification with his or her family. In cases where no parents or other members of the family can be found, the child shall be accorded the same protection as any other child permanently or temporarily deprived of his or her family environment for any reason, as set forth in the present Convention.

63 Children on the run: Unaccompanied Children Leaving Central America and Mexico and the need for International Protection, above n33, 6 .

${ }^{64}$ Usually there will be more than one element combined per person, e.g. a political opponent who belongs to a religious or national group, or both, and the combination of such reasons in his person may be relevant in evaluating his well-founded fear.

Handbook and Guidelines on Procedures and Criteria for Determining Refugee Status under the 1951 Convention and the 1967 Protocol Relating to the Status of Refugees, above n 8, 15-16 [66-67].

$65 \mathrm{Ibid}$. at 8. 


\section{Cartagena Declaration}

The Preamble and Conclusion 3 of the Cartagena Declaration underscore its character as a regional instrument complimenting the universal refugee system. The Declaration states that "the definition or concept of a refugee to be recommended for use in the region is one which, in addition to containing the elements of the 1951 Convention and the 1967 Protocol, includes among refugees persons who have fled their country because their lives, safety or freedom have been threatened by generalized violence, foreign aggression, internal conflicts, massive violations of human rights or other circumstances which have seriously disturbed public order." 66

In turn and bearing in mind the progressive development of international law, the Inter-American Court of Human Rights considers that the obligations under the right to seek and receive asylum are operative with respect to persons who meet aspects of the expanded definition of the Cartagena Declaration. Such asylum-related obligations respond not only to the dynamics of forced displacement, but also to the challenges of protection derived from other displacement patterns today. The Court, therefore, has argued that recent developments in refugee law have led States to grant international protection under refugee status to persons fleeing their country of origin due to generalized violence, foreign aggression, internal conflicts, massive violations of human rights, or other circumstances that have seriously disturbed the public order. ${ }^{67}$ For the Court, such criteria reflect an increasing tendency in the region towards a more inclusive definition to be considered by States to grant refugee protection to persons whose need for international protection is evident. ${ }^{68}$

It is worth mentioning that although the Declaration is not legally binding, the practices of States in applying its principles in terms of domestic legislation and policies indicate that it has been accepted as a fundamental element of the refugee protection framework in Latin America. ${ }^{69}$ Unfortunately, the United States and Canada have not adopted these principles within their domestic law.

As a result, both definitions and interpretation work harmoniously and complimentarily. It does not mean that a person must meet the elements of both definitions to be recognized as a refugee; it is sufficient that a person meets but one. If a person meets both definitions, however, their refugee status is indeed reinforced.

66 Cartagena Declaration. Definition of refugee.

67 Rights and Guarantees of Children in the Context of Migration and/or in Need of International Protection, above n 16, 32

68 Ibid.

69 UNHCR, above n 25, 15 [40]. 


\section{LEGAL IMPLICATIONS}

As of this writing, the Refugee Convention has been ratified by Canada and Mexico, though not by the United States; ${ }^{70}$ and by all Central American countries. ${ }^{71}$ Despite this significant achievement in the context of mixed migration flows, in our opinion, the mere existence of laws recognizing the rights of refugees is not be sufficient to ensure the protection of unaccompanied refugee children. This will require far greater administrative and judicial efforts, in conjunction with a human rights centered approach to immigration policies.

We can illustrate the above with an example: if a law exists, it requires effective implementation. This would require rapid identification of potential minor refugees coupled with allowing them to submit asylum claims, while providing them with protection and administrative assistance, including the appointment of guardians and the provision of gender and age-sensitive counseling. All of these efforts would need to be tracked, always being cognizant of the need for confidentiality and a supportive environment. Necessary measures would also include identifying unaccompanied and separated children; briefing and/or conducting information campaigns appropriate to the age, gender, and language of recipients, in a manner understandable to children.

The Inter-American Court of Human Rights has found that sovereign authority States are entitled to establish immigration policies as well as to put in place mechanisms to control entry and departure from their territory of persons who are not nationals. However, it has consistently underscored that such policies must be consistent with the human rights protection framework established in the American Convention, ${ }^{72}$ which recognizes the right to seek and receive asylum. This argument of the Court does not only apply to said regional instrument, but also to other international instruments related to human rights, such as the International Covenant on Civil and Political Rights, the Convention of the Rights of the Child, and the 1951 Convention relating to Refugee Status.

As a supporting argument, international human rights law obliges States to respect relevant international obligations enshrined in humanitarian law and refugee law and, in the case of Latin America, from the Cartagena Declaration. Therefore, all such international instruments are interrelated and converge as a whole without being contradictory to each other. ${ }^{73}$ An example

70 Signed by Canada on 4 June 1969, signed by México on 7 June 2000.

UNHCR, States Parties to the Convention and the Protocol, available at http://wrew.unhcr. org/pages/49da0e466.html.

71 Signed by Honduras on 23 March 1992, signed by Belize on 27 June 1990, signed by Costa Rica on 28 March 1978, signed by Guatemala on 22 September 1983, signed by Panama on 2 August 1978, signed by El Salvador on 28 April 1983 and signed by Nicaragua on 28 March 1980.

72 Vélez Loor v. Panamá, 218 Inter-Am Court HR (Ser C) 30 [97] (2010).

73 United Nations High Commissioner for Human Rights, International Human Rights Law, available at http://www.ohchrorg/EN/ProfessionalInterest/Pages/InternationalLaw.aspx. 
of how they are interconnected and complement each other is that although there is no internationally accepted definition of what constitutes persecution, international human rights law has played a significant role in clarifying different forms of persecution in order to understand and establish this concept on a case-by case basis.

\section{Non-Refoulement}

In affording proper treatment to unaccompanied refugee children, States must fully respect non-refoulement 74 obligations deriving from international human rights, humanitarian and refugee law and, in particular, they must respect the obligations set forth in Article $33^{75}$ of the 1951 Refugee Convention. ${ }^{76}$

In accordance with the declarative nature of the determination of refugee status, the protection provided by the principle of non-refoulement applies to all (potential) refugees, even if they have not yet been deemed refugees by authorities based on the requirements of the definition of Article 1 of the 1951 Convention and its Protocol ${ }^{77}$ or of the broader definition of refugee status. In other words, it also applies to child asylum seekers, whose status has not yet been determined and to unaccompanied refugee children who have not yet been officially recognized as such. ${ }^{78}$

The protection may also be invoked by those who wish to assert their right to seek and receive asylum and who are either at the border or have crossed it without being legally or officially admitted into the territory of the receiving country. ${ }^{79}$ Otherwise, this right would become illusory and deprived of content, value and effect. This necessarily means that such persons should not be rejected at the border or expelled without undergoing an adequate and individualized analysis of their requests. ${ }^{80}$ In addition, under international refugee law, the prohibition of refoulement to a risk of persecution is applicable

74 Prohibition on forcibly returning claimants to their country of origin.

75 The 1951 Convention Relating to the Status of Refugee, opened for signature 28 July 1951, UNTS 150 (entered into force on 22 April 1954) article 33. 1. No Contracting State shall expel or return ("refouler") a refugee in any manner whatsoever to the frontiers of territories where his life or freedom would be threatened on account of his race, religion, nationality, membership of a particular social group or political opinion. 2. The benefit of the present provision may not, however, be claimed by a refugee whom there are reasonable grounds for regarding as a danger to the security of the country in which he is, or who, having been convicted by a final judgment of a particularly serious crime, constitutes a danger to the community of that country.

76 General Comment No. 6: Treatment of Unaccompanied and Separated Children Outside their Country of Origin, above n 19, 10.

77 Pacheco Tineo Family v. Bolivia, 272 Inter-Am Court HR (Ser c) 48 [145] (2013).

78 ExCom, Non-refoulment,) sess $27^{\text {th }}$, No 6 [c]. (1997).

79 Ibid.

80 Pacheco Tineo Family v. Bolivia, above n 70, 49 [153]. 
to any form of forced removal, including deportation, expulsion, extradition, informal transfer of renditions, and non-admission at the border in the circumstances described above. ${ }^{81}$ When it comes to unaccompanied children, this general rule is important for identifying possible refugees among mixed migration movements for it gives them a chance to explain their reasons for not being returned and, therefore, allows authorities in the receiving state to determine whether there are risks threatening their life, freedom or security should they be returned to their country of origin. Simultaneously, during the assessment, non-refoulement helps States to determine the best interests of unaccompanied children, even if they do not meet the elements of the definition of being a refugee, they may require complimentary protection.

Although refugee law has been the pioneering branch of international law in adopting the principle of non-refoulement, there are also other international instruments ${ }^{82}$ that have adopted it. One example is the Convention against Torture and other Cruel, Inhuman or Degrading Treatment or Punishment, which provides that States will not expel, return or extradite a person to another state where there are substantial grounds to believe that he or she would be in danger of being subjected to torture. Domestically, states must implement measures to respond to this international obligation, which aims at preventing and ensuring the non-repetition of torture.

It is important to note that non-refoulement is considered customary law, ${ }^{83}$ which means that it is binding on all States, including those which have not yet become party to the 1951 Refugee Convention. Unaccompanied children should be granted a complimentary or subsidiary status as a consequence of their rights being endangered, even if they do not properly meet refugee definitions.

\section{Access to the Asylum Procedure}

Asylum seeking children and adolescents, including those who are unaccompanied, shall enjoy access to asylum procedures and other complimen-

81 U.N. UNHCR, Advisory Opinion on the Extraterritorial Application of Non-Refoulement Obligations Under the 1951 Convention Relating to the Status of Refugees AND ITs 1967 PRotocol 3 (2007).

82 The Covenant on Civil and Political Rights, Inter-American Convention on Human Rights, the 1984 Convention Against Torture and other Cruel, Inhuman or Degradation Treatment or Punishment.

83 For a rule to become part of customary international law, two elements are required: consistent State practice and opinio juris, that is, the understanding held by States that the practice at issue is obligatory due to the existence of a rule requiring it.

North Sea Continental Shelf, Judgment, (Germany v. Denmark; Germany v. Netherlands) ICJ Rep 1969, 3 [74] (1969).

Military and Paramilitary Activities in and against Nicaragua (Nicaragua v. United States of America), (Jurisdiction) ICJ Rep1986, 392 [77] (1984). 
tary mechanisms providing international protection, irrespective of their age. This right also allows children to request asylum in the country of asylum or at the border. Therefore, children may not be rejected at the border before there is an adequate and individualized analysis of his or her request with due guarantees according to the respective procedures. ${ }^{84}$ It is necessary that States allow unaccompanied children access to their territory as a prerequisite to the initial assessment process, ${ }^{85}$ independently, regardless of whether she or he has documents to enter or stay. ${ }^{86}$

In addition, in spite of the reasons for leaving the country of their habitual residence, the receiving State should implement a procedure for determining if a child requires international protection. ${ }^{87}$ In the event that any authority of the country of asylum or transit learns about the presence of an unaccompanied child, that child should be processed under an asylum procedure, even if he or she does not appear to be a refugee. This referral to a process could be crucial to protect the child's rights during his or her temporary or permanent stay in the country of destination or transit, even if the child finally decides to transit to another country to receive international protection.

During such a process, relevant information about the child, such as personal history and physical and psychological health conditions, and the environment in which the migration took place, will be useful to identify potential candidates who qualify for international protection. This analysis will assist in determining specific situations of potential risk of violation of rights in the child's country of origin, or in the transit or recipient country. All of these elements need to be considered in order to warrant complimentary protection or for exposing other protection or humanitarian assistance requirements, such as those resulting from torture, domestic violence, trafficking, or trauma. ${ }^{88}$

84 Rights and Guarantees of Children in the Context of Migration and/or in Need of International Protection, above n 16, 5 [20].

85 General Comment No. 6: Treatment of Unaccompanied and Separated Children Outside their Country of Origin, above n 19, 20.

86 The legislation of certain States imposes severe penalties on nationals who depart from the country in an unlawful manner or remain abroad without authorization. Where there is reason to believe that a person, due to his illegal departure or unauthorized stay abroad is liable to such severe penalties, his recognition as a refugee will be justified if it can be shown that his motives for leaving or remaining outside the country are related to the reasons enumerated in Article 1 A (2) of the 1951 Convention.

Handbook and Guidelines on Procedures and Criteria for Determining Refugee Status under the 1951 Convention and the 1967 Protocol Relating to the Status of Refugees, above n 8, $15[61]$.

87 U.N UnhCR, Guidelines on Statelessness No 2: Procedures for Determining Whether an Individual is a Stateless Person, UN Doc HCR/GS/12/02, 26-27 (2012).

88 Promotion and Protection for All Human Rights, Givil, Political, Economic, Social and Gultural Rights, Including the Right to Development - Report of the Special Rapporteur on the Human Rights of Migrants - UN Doc A/HRG/11/7, 35, (2009). 
In addition, and with the aim that unaccompanied children be recognized as refugees, as well as to ensure that their inclusion in Mexican society is effective, Mexican authorities should explore an accommodation alternative for children in host families, as established in law. ${ }^{89}$ This is necessary for their integration for the Mexican society and it also means that the international protection has been carried out.

\section{Gonclusions}

Mixed migration movements differ around the world. However, in Mexico and Central America this phenomenon has unique features as they pertain to unaccompanied refugee children. These children, who are fleeing from persecution caused by organized armed crime and domestic violence perpetrated by caregivers or parents in the country of origin, face problems such as travelling without official documentation, and are frequently exposed to criminal smuggling and trafficking as the only accessible options to arrive at a final destination.

In this context, it can be said that unaccompanied refugee children in the region are far more vulnerable in comparison to adults in similar situations, due to the particular conditions of age, gender, maturity, level of education, ethnicity, economic dependence, etc. The combination of these factors makes them particularly vulnerable prey for smugglers and traffickers and/or easy targets of abuse, exploitation, and victimization.

Although some positive developments for protecting unaccompanied refugee children in the region have unfolded, the challenge of identifying them among mixed migration flows remains. In order to live up to the humanitarian sense of international protection, its implementation requires adopting an age and gender-sensitive approach.

Mexico and Central America must be prepared in a variety of ways and fronts to meet and deliver on these challenges by implementing appropriate mechanisms to identify unaccompanied refugee children within mixed migration flows, and to respect and protect their rights in accordance with Refugee Law. States must adopt and promote the effective application of relevant international human rights norms and standards by creating and adapting legal and policy frameworks for the benefit of children.

89 Comisión Nacional de Derechos Humanos, Informe sobre la problemática de niñas, niños y adolescentes centroamericanos en contexto de migración internacional no acompañados en su tránsito por México, y con necesidades de protección internacional, México, (2016).

Received: June 5th, 2018.

Accepted: November 17th, 2018. 